\title{
Concentrations of oestrone sulphate, androgens and LH in the peripheral plasma of mating stallions
}

\author{
G. Bono, D. Minori, ${ }^{*}$ R. Gaiani and M. Mattioli
}

Istituto di Fisiologia Veterinaria e Cattedra di Fisiologia Generale e Speciale Veterinaria II e Fisica Biologica, Università degli Studi di Bologna, Via Belmeloro, 8/2 Bologna and *Esercito Italiano, Centro Militare Allevamento e Rifornimento Quadrupedi, Grosseto, Italy

\begin{abstract}
Summary. Peripheral plasma levels of oestrone sulphate, androgens and LH were studied in two mating stallions. A peak of oestrone sulphate was observed $7 \cdot 5-15$ min after exposure to an oestrous female. No variations were recorded in $\mathrm{LH}$ concentrations. The concentrations of testosterone, dihydrotestosterone and androstenedione increased similarly after mating and on a day of sexual inactivity.
\end{abstract}

\section{Introduction}

The ability of the stallion testis to synthesize androgens, such as testosterone, dihydrotestosterone and androstenedione, and normally to produce very large quantities of oestrogens has been well established (Nyman, Geiger \& Goldzieher, 1959; Savard \& Goldzieher, 1960; Lindner, 1961; Velle, 1966; Ganjam \& Kenney, 1975). Conjugated oestrogens such as oestradiol-17 $\beta$ sulphate and oestrone sulphate have also been identified in stallion testicular tissue (Raeside, 1969).

The patterns and levels of plasma androgens and oestrogens have been investigated over 24-h periods in different seasons of the year and in artificial photoperiods. However, the results are widely contrasting, especially with regard to the plasma level changes of these hormones (Cox, Williams, Rowe \& Smith, 1973; Cox \& Williams, 1975; Kirkpatrick et al., 1976; Sharma, 1976; Kirkpatrick, Wiesner, Kenney, Ganjam \& Turner, 1977; Thompson, Pickett, Berndtson, Voss \& Nett, 1977; Thompson, Pickett \& Nett, 1978; Raeside, 1978/1979; Ganjam, 1979; Raeside, George, Rosskopf \& Bosu, 1980). Plasma LH concentration has been related to seasonal or photoperiodic changes as well as to sexual behaviour and seminal characteristics (Thompson et al., 1977).

The variations in plasma $\mathrm{LH}$ and androgens in horses during sexual activity have been determined (Cox \& Williams, 1975; Ganjam \& Kenney, 1975).

The aim of the present study was to examine the variations in plasma concentration of LH, androgens and oestrone sulphate in stallions with respect to sexual stimulation.

\section{Materials and Methods}

\section{Animals}

Two stallions (A, Thoroughbred and D, Anglo-Arab), aged 7 and 9 years were used between February and May.

Blood samples were always taken between 08:00 and 14:30 h. Jugular vein blood was 
collected by venepuncture from each stallion into heparinized tubes and was centrifuged immediately at $2300 \mathrm{~g}$ for $10 \mathrm{~min}$ at $4^{\circ} \mathrm{C}$. Plasma was removed and stored at $-20^{\circ} \mathrm{C}$ until assay.

\section{Experimental design}

Seven plasma samples from each stallion were taken on a day when there was not sexual activity (i.e. non-mating day). Subsequently, the animals were allowed to mount an oestrous mare (mating days), and on each of the 4 days a sample was taken just before exposure to the mare, at exposure $(08: 30 \mathrm{~h})$ and then at $7 \frac{1}{2}, 15$ and $30 \mathrm{~min}$ and $1,2,4$ and $6 \mathrm{~h}$.

\section{Hormone assays}

Androgens. Radioactive tracers, about 2000 d.p.m. of testosterone, dihydrotestosterone and androstenedione, were added to $0.5 \mathrm{ml}$ plasma, which was then extracted with $7 \mathrm{ml}$ diethyl ether. The ether extract was dried and the residue was redissolved in $200 \mu$ diethyl ether and placed onto a silica gel plate. Partition chromatography with a solvent system of chloroform:ethyl acetate $(85: 15 \mathrm{v} / \mathrm{v})$ was performed as described by Paradisi, Lodi, Bolelli \& Venturoli (1980). The fractions containing the three androgens were dried in a vacuum and the residue was

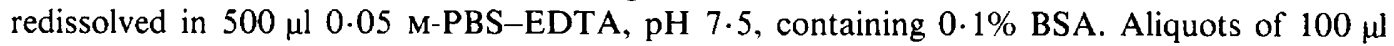
were taken in duplicate for RIA. A $200 \mu \mathrm{l}$ sample was placed into a scintillation vial and counted. Recovery was $72.7 \pm 1.29 \%$ for $\left[1,2,6,7-{ }^{3} \mathrm{H}\right]$ testosterone, $78.6 \pm 1.64 \%$ for $\left[1,2,3-{ }^{3} \mathrm{H}\right]$ dihydrotestosterone and $75 \cdot 6 \pm 1 \cdot 26 \%$ for $\left[1,2,6,7-{ }^{3} \mathrm{H}\right]$ androstenedione. The blank value obtained by extracting, under the same conditions, an equal amount of double-distilled water was $4.12 \pm 0.45 \mathrm{pg}$ testosterone/tube, $2.81 \pm 0.43 \mathrm{pg}$ dihydrotestosterone/tube and 3.48 $\pm 0.68 \mathrm{pg}$ androstenedione/tube. The intra-assay and inter-assay precisions were expressed as the coefficient of variation and were respectively: for testosterone, 5.1 and $10.1 \%$; for dihydrotestosterone, 7.8 and 5.6\%; and for androstenedione, 6.7 and $11.0 \%$ (all values based on 10 assays).

$L H$. A heterologous radioimmunoassay using an anti-ovine $\mathrm{LH}$ serum in combination with labelled ovine LH was developed as described by Bono, Gaiani \& Tamanini (1979). The antiserum was raised in a rabbit to NIH-LH-S20 and used at a final dilution of 1:40000. Ovine LH (LER-1374A) was radioiodinated with ${ }^{125}$ I to a specific activity of $50-100 \mu \mathrm{Ci} / \mu \mathrm{g}$. Highly purified equine LH (LER-958-1) was used as standard in the assay. The antiserum showed a $35.7 \%$ cross-reaction with equine FSH (LER-1686-2). The sensitivity of assay, defined as the mass of hormone required to suppress the binding of the labelled hormone to $90 \%$ of the binding achieved with no hormone added (B/Bo), was $266.9 \pm 36.9$ (s.e.m.) pg/tube. The intra- and inter-assay precisions for replicate determinations of a pool of plasma were always $<10 \%$.

Oestrone sulphate. The antiserum for the heterologous radioimmunoassay was raised in rabbits to oestrone-3-hemisuccinate-BSA and used at a working dilution of 1:20000. Cross-reactions (\%) were: oestrone, 100; oestrone sulphate, 20; oestrone glucuronide, 18; oestradiol- $17 \alpha$ and oestradiol- $17 \beta, 0.4$; oestriol, $<0.01$. The antigen was $\left[2,4,6,7-{ }^{3} \mathrm{H}\right]$ oestrone, used at 80000 d.p.m./ml. The plasma sample was diluted $1: 50(\mathrm{v}: \mathrm{v})$ with $0.05 \mathrm{M}$-PBS-EDTA and $1 \mathrm{ml}$ aliquot was extracted with $5 \mathrm{ml}$ diethyl ether by vortexing for $30 \mathrm{sec}$. The supernatant containing the unconjugated oestrone was discarded. Then $100 \mu \mathrm{l}$ antigen and $100 \mu \mathrm{l}$ antiserum were added to $100 \mu \mathrm{l}$ diluted plasma and incubated overnight at $4^{\circ} \mathrm{C}$. Separation of free from bound hormone was obtained by adding $1 \mathrm{ml} 0.3 \%$ dextran-coated charcoal and by centrifugation at $3200 \mathrm{~g}$ for $15 \mathrm{~min}$ at $4^{\circ} \mathrm{C}$. A standard curve was produced with known amounts of oestrone sulphate $(15.6,31 \cdot 2,62 \cdot 5,125,250,500,1000$ and $2000 \mathrm{pg})$. The recovery of oestrone sulphate was calculated by previously adding $\sim 1500$ d.p.m. [6,7- 
${ }^{3} \mathrm{H}$ loestrone sulphate to the plasma. Accuracy and precision were determined by adding known amounts of oestrone sulphate to equine plasma pools. The reliability of the method was as follows (values are mean \pm s.e. for the no. of samples in parentheses).

\begin{tabular}{|c|c|}
\hline \multicolumn{2}{|l|}{ Accuracy and precision } \\
\hline Stallion plasma pool $(\mathrm{ng} / \mathrm{ml})$ & $247 \cdot 8 \pm 10 \cdot 2(10)$ \\
\hline Stallion plasma pool $+50 \mathrm{ng} / \mathrm{ml}$ & $326.9 \pm 3 \cdot 5 \quad(10)$ \\
\hline Stallion plasma pool $+250 \mathrm{ng} / \mathrm{ml}$ & $506 \cdot 1 \pm 17 \cdot 2(10)$ \\
\hline Castrated male plasma pool $(\mathrm{ng} / \mathrm{ml})$ & $0.23 \pm 0.1 \quad(10)$ \\
\hline Castrated male plasma pool $+25 \mathrm{ng} / \mathrm{ml}$ & $19.7 \pm 1.4$ \\
\hline Castrated male plasma pool $+250 \mathrm{ng} / \mathrm{ml}$ & $231 \cdot 6 \pm 4 \cdot 5$ \\
\hline Inter-assay precision (\%) & $7 \cdot 3$ \\
\hline Intra-assay precision (\%) & $4 \cdot 1$ \\
\hline Recovery (\%) & $91.4 \pm 0.6$ \\
\hline Blank (pg/tube) & $3 \cdot 3 \pm 2 \cdot 3$ \\
\hline Sensitivity (pg) & $25 \cdot 7 \pm 3 \cdot 1$ \\
\hline
\end{tabular}

The reliability of the method was further assessed as follows. The equine plasma was diluted 1:50 (v:v) with $0.9 \%(\mathrm{w} / \mathrm{v}) \mathrm{NaCl}$ and a $1 \mathrm{ml}$ aliquot was extracted with $5 \mathrm{ml}$ diethyl ether. The supernatant was then discarded. To the residue $1 \mathrm{ml} 0.2 \mathrm{M}$-acetate buffer, $\mathrm{pH} 4 \cdot 2$, containing 250 units sulphatase (Sigma, Type H-I) was added and the mixture incubated overnight at $37^{\circ} \mathrm{C}$. The aqueous material was extracted with $10 \mathrm{ml}$ diethyl ether and the extract evaporated. The dried residue was dissolved in $200 \mu \mathrm{l}$ benzene: methanol $(85: 15 \mathrm{v} / \mathrm{v})$ and transferred onto a Sephadex LH-20 microcolumn $(7.5 \times 0.5 \mathrm{~cm})$. Chromatography and radioimmunoassay were performed as described by Seren, Bono \& Bolelli (1976). A standard curve was produced with $3 \cdot 9,7 \cdot 8,15 \cdot 6,31 \cdot 2,62 \cdot 5,125,250$ and $500 \mathrm{pg}$ oestrone. To correct for the actual amounts of oestrone sulphate these values should be multiplied by $1 \cdot 38$. The values for oestrone sulphate in two equine plasma pools assayed by the two methods (without and with enzymic hydrolysis respectively) were $221 \cdot 3 \pm 6 \cdot 5(n=6)$ and $225 \cdot 2 \pm 9 \cdot 1(n=6) \mathrm{ng} / \mathrm{ml}$ for Pool A and $268 \cdot 2 \pm$ $8 \cdot 8(n=6)$ and $284 \cdot 8 \pm 7 \cdot 0(n=6) \mathrm{ng} / \mathrm{ml}$ for Pool B.

\section{Patterns of mating behaviour}

Some behavioural patterns in the two mating stallions were also investigated in relation to arousal (courtship, vocalizations, lipcurl and intromission latency) and consummation (intromission frequency and ejaculatory frequency).

\section{Results}

The concentration of testosterone in the plasma samples of the two stallions on the non-mating day ranged from 390 to $670 \mathrm{pg} / \mathrm{ml}$ in the morning and from 1300 to $1700 \mathrm{pg} / \mathrm{ml}$ in the early afternoon. A similar pattern for testosterone was observed on mating days, although on such days peak testosterone values occurred 5 times out of 8 at 12:30 h and were lower thereafter, although they were maintained at quite high levels. On the other 3 occasions, the testosterone concentration continued to rise over the entire experimental period. The highest levels of testosterone on the 4 mating days were $1261,2134,1403$ and $1041 \mathrm{pg} / \mathrm{ml}$ in Stallion D and $1318,987,1759$ and $3006 \mathrm{pg} / \mathrm{ml}$ in Stallion A.

Androstenedione and dihydrotestosterone followed the same pattern as testosterone, although at lower concentrations. The testosterone:androstenedione and testosterone:dihydrotestosterone ratios were $2: 1$ and $6: 1$, respectively. The correlation coefficients for the three androgens examined were 0.86 for testosterone and androstenedione, 0.8 for testosterone and dihydrotestosterone and 0.68 for androstenedione and dihydrotestosterone in Stallion $\mathrm{A}$ and $0.91,0.81$ and 0.71 in Stallion D. 
Cyclic fluctuations in LH levels were found in each stallion on the non-mating day as well as on the days when they mounted. Only occasionally did an increase occur after exposure to the female. In Stallion D, the levels of LH were generally higher than in Stallion A, the highest and lowest LH levels being 38-145 and $13-59 \mathrm{ng} / \mathrm{ml}$, respectively.

Oestrone sulphate levels (Text-fig. 1) on the non-mating day ranged from 156 to $263 \mathrm{ng} / \mathrm{ml}$. Each animal exhibited a peak level of this steroid within $7 \frac{1}{2} \mathrm{~min}$ after exposure to an oestrous female (15 min on only one occasion). The maximum value of oestrone sulphate was $505 \mathrm{ng} / \mathrm{ml}$ in Stallion D and $428 \mathrm{ng} / \mathrm{ml}$ in Stallion A. These levels had returned to basal values within 30 min after exposure.

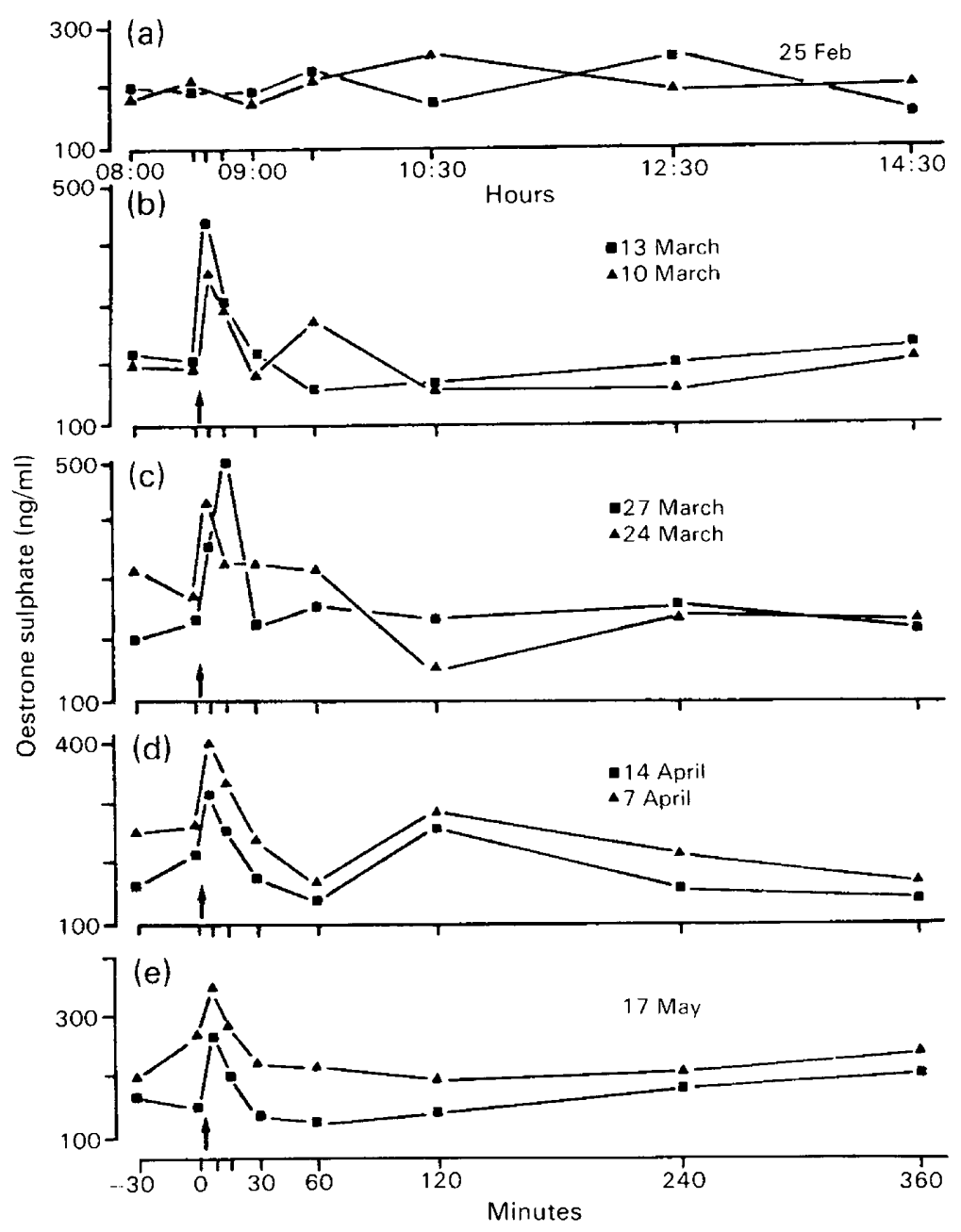

Text-fig. 1. Plasma concentrations of oestrone sulphate in two stallions on (a) a day of sexual inactivity and (b, c, d, e) on 4 days when mating (arrow) was allowed. The time of exposure to the mare $(08: 30 \mathrm{~h})$ was taken as time 0 .

Moreover, the two stallions exhibited marked differences in sexual behaviour. In Stallion A but not in Stallion D arousal was always characterized by the typical signs, but no differences were observed between the stallions in intromission latency and intromission frequency. Ejaculation latency was longer in Stallion A $(60-70 \mathrm{sec})$ than in Stallion D $(20-30 \mathrm{sec})$. 


\section{Discussion}

On the four mating days a gradual increase in peripheral plasma androgens, and especially in testosterone, was observed in both stallions $2-4 \mathrm{~h}$ after exposure to the oestrous female and mating, which took place at 08:30 h. Ganjam \& Kenney (1975) reported increased androgen concentrations in stallions 5 and 15 min after female exposure, whereas Cox \& Williams (1975) were unable to detect any changes in testosterone concentrations in response to sexual stimulation. In the present study, androgens also increased on the non-mating day between $12: 30$ and $14: 30 \mathrm{~h}$, i.e. $2-4 \mathrm{~h}$ later than the increase observed after mating. The changes in androgen concentrations observed here might well depend on the diurnal variations of these hormones, although Ganjam (1979) could not detect any diurnal variations of plasma androgens in the horse. Too few data are available to establish with sufficient reliability the extent to which the variability found in this study can be attributed to sexual excitement.

The concentration changes of oestrone sulphate were unusual. On the non-mating day the plasma concentrations in both stallions were extremely high, nearly 100 -fold higher than those of androgens. This is in agreement with previous findings (Raeside, 1978/1979; Raeside et al., 1980). However, exposure to an oestrous mare and mating produced a rise in oestrone sulphate levels with peak values 7.5-15 min after exposure. According to Raeside (1978/1979), oestrone sulphate could provide a sensitive index of testicular endocrine function in the stallion, because there is a close correlation between plasma levels of oestrone sulphate and oestrogens and the seasonal changes of sexual activity in the stallion (see also Thompson et al., 1977). The biological significance of oestrone sulphate can only be conjectured at present. In this context, as oestrogens and oestrone sulphate, synergistically with testosterone, regulate accessory sex gland activity in castrated boars (Joshi \& Raeside, 1973) and testicular production of oestrone sulphate in the stallion is even greater than in the boar, one can suppose that hormonal control of sex gland activity may include oestrogen of testicular origin in the stallion too. Oestrone sulphate may also be involved in maintenance of libido in the stallion, since oestradiol is able to restore libido in geldings (Thompson, Pickett, Squires \& Nett, 1980). The role of oestrone sulphate in the stallion requires further study.

In our investigation, sexual stimulation had no significant effect on plasma LH levels. However Convey, Bretschneider, Hafs \& Oxender (1971) and Smith, Mongkonpunya, Hafs, Convey \& Oxender (1973) were unable to confirm the rise in LH levels after ejaculation in bulls that was reported by Katongole, Naftolin \& Short (1971) and no increase in LH after mating has been observed in the rabbit (Hilliard, Pang, Penardi \& Sawyer, 1975).

Finally, the differences in sexual behaviour reported in the two stallions did not seem to be reflected in differences in the magnitude of androgen and oestrone sulphate variations.

We thank Dr L. E. Reichert, Jr for ovine LH (NIH-LH-S20 and LER-1374 A), equine LH (LER-958-1) and equine FSH (LER-1686-2); and Mr S. Mongiorgi for technical assistance.

This study was supported by C.N.R. grant CT81.00355.04.

\section{References}

Bono, G., Gaiani, R. \& Tamanini, C. (1979) Dosaggio radioimmunologico dell'LH equino e della PMSG. La Clinica Veterinaria 102, 446-450.

Convey, E.M., Bretschneider, E., Hafs, H.D. \& Oxender, W.D. (1971) Serum levels of LH, prolactin and growth hormone after ejaculation in bulls. Biol. Reprod. 5, 20-23.
Cox, J.E. \& Williams, J.H. (1975) Some aspects of the reproductive endocrinology of the stallion and cryptorchid. J. Reprod. Fert., Suppl. 23, 75-79.

Cox, J.E., Williams, J.H., Rowe, P.H. \& Smith, J.A. (1973) Testosterone in normal, cryptorchid and castrated male horses. Eq. vet. J. 5, 85-90.

Ganjam, V.K. (1979) Episodic nature of the $\triangle^{4}$-ene and 
$\triangle^{5}$-ene steroidogenetic pathways and their relationship to the adrenogonadal axis in stallions. $J$. Reprod. Fert., Suppl. 27, 67-71.

Ganjam, V.K. \& Kenney, R.M. (1975) Androgens and oestrogens in normal and cryptorchid stallions. $J$. Reprod. Fert., Suppl. 23, 67-73.

Hilliard, J., Pang, C., Penardi, R. \& Sawyer, C.H. (1975) Effect of coitus on serum levels of testosterone and LH in male and female rabbits. Proc. Soc. exp. Biol. Med. 149, 1010-1014.

Joshi, H.S. \& Raeside, J.I. (1973) Synergistic effects of testosterone and oestrogens on accessory sex glands and sexual behaviour of the boar. J. Reprod. Fert. 33, $411-423$.

Katongole, C.B., Naftolin, F. \& Short, R.V. (1971) Relationship between blood levels of luteinizing hormone and testosterone in bulls, and the effects of sexual stimulation. J. Endocr. 50, 457-466.

Kirkpatrick, J.F., Vail, R., Denous, S., Schwendes, S., Backer, C.B. \& Wiesner, L. (1976) Diurnal variation of plasma testosterone in wild stallions. Biol. Reprod. 15, 98-101.

Kirkpatrick, J.F., Wiesner, L., Kenney, R.M., Ganjam, V.K. \& Turner, J.W., Jr (1977) Seasonal variation in plasma androgens and testosterone in the North American wild horse. J. Endocr. 72, 237-238.

Lindner, H.R. (1961) Androgens and related compounds in the mammalian testis and their significance in the control of male fertility. Br. med. Bull. 26, 87-91.

Nyman, M.A., Geiger, T. \& Goldzieher, J. W. (1959) Biosynthesis of estrogen by the perfused stallion testis. J. biol. Chem. 234, 16-18.

Paradisi, R., Lodi, S., Bolelli, G. \& Venturoli, S. (1980) Radioimmunoassay of free oestrogens and free androgens in the same plasma sample after extraction and chromatographic separation. Acta endocr., Copenh. 94, 229-234.

Raeside, J.I. (1969) The isolation of oestrone sulphate and oestradiol- $17 \beta$ sulphate from stallion testis. Can. J. Biochem. 47, 811-815.
Raeside, J.I. (1978/1979) Seasonal changes in the concentration of oestrogens and testosterone in the plasma of the stallion. Anim. Reprod. Sci. 1, 205-212.

Raeside, J.I., George, W., Rosskopf, E. \& Bosu, W.T.K. (1980) Plasma levels of testosterone and estrogens in the stallion. Proc. 9th Int. Congr. Anim. Reprod. \& A.I., Madrid, vol. 3, 76 .

Savard, K. \& Goldzieher, J.W. (1960) Biosynthesis of steroids in stallion testis tissue. Endocrinology 66, 617-624.

Seren, E., Bono, G. \& Bolelli, G. (1976) Peripheral plasma levels of oestrone, oestradiol-17 $\beta$, oestradiol$17 \alpha$ and oestriol in the bovine during oestrus cycle and pregnancy. Arch. Vet. It. 27, 155-166.

Sharma, O.P. (1976) Diurnal variation of plasma testosterone in stallions. Biol. Reprod. 15, 158-162.

Smith, O.W., Mongkonpunya, K., Hafs, H.D., Convey, E.M. \& Oxender, W.D. (1973) Blood serum testosterone after sexual preparation for ejaculation or after injections of LH or prolactin in bulls. J. Anim. Sci. 37, 979-984.

Thompson, D.L., Jr, Pickett, B.W., Berndtson, W.E., Voss, J.L. \& Nett, T.M. (1977) Reproductive physiology of the stallion. VIII. Artificial photoperiod, collection interval and seminal characteristics, sexual behavior and concentrations of $\mathrm{LH}$ and testosterone in serum. J. Anim. Sci. 44, 656-664.

Thompson, D.L., Jr, Pickett, B.W. \& Nett, T.M. (1978) Effect of season and artificial photoperiod on levels of estradiol-17 $\beta$ and estrone in blood serum of stallions. J. Anim. Sci. 47, 184-187.

Thompson, D.L., Jr, Pickett, B.W., Squires, E.L. \& Nett, T.M. (1980) Sexual behavior, seminal $\mathrm{pH}$ and accessory sex gland weights in geldings administered testosterone and (or) estradiol-17ß.J.Anim. Sci. 51, $1358-1366$.

Velle, V. (1966) Urinary oestrogens in the male. $J$. Reprod. Fert. 12, 65-73.

Received 3 August 1981 